\title{
Biometric and chemical characteristics of sugarcane varieties for use as forage in limiting soil water conditions
}

\author{
Janieire Dorlamis Cordeiro Bezerra ${ }^{* *}$, Geane Dias Gonçalves Ferreira², José Maurício de Souza \\ Campos $^{2}$, Mauro Wagner de Oliveira ${ }^{3}$, Albericio Pereira de Andrade ${ }^{1,2}$, José Ribamar Silva do \\ Nascimento Júnior ${ }^{1}$
}

\footnotetext{
${ }^{1}$ Universidade Federal da Paraíba, Programa de Doutorado Integrado em Zootecnia, Areia, PB, Brazil.

${ }^{2}$ Universidade Federal Rural de Pernambuco, Unidade Acadêmica de Garanhuns, Garanhuns, PE, Brazil.

${ }^{3}$ Universidade Federal de Alagoas, Centro de Ciências Agrárias, Rio Largo, AL, Brazil.
}

\begin{abstract}
This study aimed to evaluate the biometric and chemical characteristics of five sugarcane varieties (RB 863129, RB 867515, RB 92579, RB 943365, and RB 98710) grown in a semi-arid climate for use as forage. The experiment was designed as randomized blocks, in a $5 \times 2$ factorial arrangement (five sugarcane varieties and two evaluation times, 407 and 483 days). Response variables included dry matter productivity, morphological characteristics, chemical composition, digestibility, and ratios among neutral detergent fiber (NDF), Brix, and Pol. For the biometric analyses, there was an interaction effect between the evaluated varieties and harvest times on the variables fresh matter yield, uncovered internodes, and stalk density (MID - middle internode density). Regarding stalk density (MID), at 407 days, there was no significant difference among the varieties $\left(1.19 \mathrm{~g} \mathrm{~cm}^{-3}\right)$. For the fractionated parts, there was an effect of harvest time on the amount of fresh matter and dry matter of tops produced, which was highest at 407 days of age. A significant difference was detected among the varieties for contents of dry matter and total digestible nutrients. The variable in vitro neutral detergent fiber digestibility was influenced by the time, decreasing by $53.62 \mathrm{~g} \mathrm{~kg}^{-1}$ at 483 days. In the analysis of Brix and Pol yields per hectare, it was observed that variables ton of Brix per hectare and ton of sucrose per hectare averaged 15.12 and $10.14 \mathrm{t} \mathrm{ha}^{-1}$, respectively, and the NDF:Brix and NDF:Pol ratios were higher for variety RB 863129, with 2.93 and 3.68, respectively. Variety RB 867515 is suggested for forage production in semi-arid conditions, as it is best adapted to the local soil-climatic conditions and to the water deficit, especially at 407 days.
\end{abstract}

Key Words: feeding, forage, semiarid, sugar

\section{Introduction}

The development of animal husbandry in semi-arid climate regions faces obstacles, especially in terms of forage production. The rainfall pattern, which is within the annual range of $300-800 \mathrm{~mm}$, is distributed unevenly, with only three to four months of rainy season, generating a negative water balance (Embrapa, 2011). This ultimately leads to a decrease in the profitability of livestock systems, since low-forage production results in lower animal performance rates or a greater need for purchasing food, thereby increasing production costs.

Received: August 3, 2016

Accepted: March 16, 2017

*Corresponding author: janieirebezerra@hotmail.com

http://dx.doi.org/10.1590/S1806-92902017000500003

How to cite: Bezerra, J. D. C.; Ferreira, G. D. G.; Campos, J. M. S.; Oliveira, M. W.; Andrade, A. P. and Nascimento Júnior, J. R. S. 2017. Biometric and chemical characteristics of sugarcane varieties for use as forage in limiting soil water conditions. Revista Brasileira de Zootecnia 46(5):384-392.

Copyright (C) 2017 Sociedade Brasileira de Zootecnia. This is an Open Access article distributed under the terms of the Creative Commons Attribution License (http://creativecommons.org/licenses/by/4.0/), which permits unrestricted use, distribution, and reproduction in any medium, provided the original work is properly cited.
The livestock activity in these regions has its importance in the socioeconomic-spatial context. The dairy livestock in the state of Pernambuco, Brazil, for instance, occupies an area of $20.278 \mathrm{~km}^{2}$, with the participation of 10,000 producers, most of whom conduct the activity in areas smaller than 50 ha and account for almost $75 \%$ of the produced milk (IBGE, 2013).

Thus, the forage support should be planned, seeking alternatives that meet the local conditions, such as complementary roughage sources adapted to the semi-arid conditions and with good dry matter (DM) production in a small space. Sugarcane (Saccharum officinarum L.) stands out for these attributes, having a biological potential for production of up to $350 \mathrm{t} \mathrm{ha}^{-1}$ year $^{-1}$ (Landell, 2005). In addition, unlike most grasses, the sugarcane has its organic matter (OM) digestibility increased as it matures, due to the greater accumulation of sucrose (Rodrigues, 1995; Townsend et al., 2006; Toppa et al., 2010) and because the harvest period coincides with the dry season, when forage scarcity is pronounced (Borges et al., 2012).

When using sugarcane in animal feeding, producers must consider not only the productivity of varieties, but also their nutritional quality. Thus, in the selection of varieties 
with forage purpose, agronomic and chemical analyses can help in the choice of those best suited to the semi-arid conditions.

Therefore, this study aimed to evaluate agronomic and chemical characteristics of sugarcane varieties grown for forage production under low soil-water availability.

\section{Material and Methods}

The study was conducted in the semi-arid region of Pernambuco State, Brazil ( $8^{\circ} 56^{\prime} 31^{\prime \prime S}$ latitude, 36 36 $36^{\prime} 24^{\prime \prime} \mathrm{W}$ longitude, and $968 \mathrm{~m}$ altitude). The climate of the region is classified, according to the Köppen system, as a Cs'a (highaltitude forest, humid mesothermal) type, with an average annual precipitation of $838 \mathrm{~mm}$, distributed unevenly throughout the year, but with concentration between 70 and 130 days, and an average annual temperature of $23.3{ }^{\circ} \mathrm{C}$ (INMET, 2013). The relief is dissected, with deep valleys. The soil utilized in the experiment was classified as a RedYellow Ultisol (Embrapa, 2006).

Five sugarcane varieties were evaluated: RB 863129 , RB 867515, RB 92579, RB 943365, and RB 98710. The varieties were chosen because they are commonly used in the cane industry in the northeast region and have characteristics suitable for use as forage, such as high productivity, medium-high size, medium-high sucrose content, and medium-low fiber content (RIDESA, 2010, RIDESA, 2012).

The varieties belong to the Rede Interuniversitária para o Desenvolvimento do Setor Sucroalcooleiro (RIDESA). The varieties RB 863129 and RB 943365 were obtained by UFRPE (Universidade Federal Rural de Pernambuco), varieties RB 92579 and RB 98710 by UFAL (Universidade Federal de Alagoas) and RB 867515 by UFV (Universidade Federal de Viçosa). The variety RB 863129 originated from cross-center between RB 763411 with several other varieties, at random. The variety RB 867515 resulted from a poly-crossing, having variety RB 72454 as parent, fertilized with pollen of several other varieties, at the same time. The variety RB 92579 resulted from a biparental cross, having variety RB 75126 as progenitor, fertilized with pollen of the variety RB 72199. The variety RB 943365 resulted from the crossing of ROC3 $\times$ RB83100 and RB 98710 from the crossing between SP81-3250 $\times$ RB93509. All the varieties are considered young because were launched 7-19 years ago (RIDESA, 2010).

Five sugarcane varieties and two harvest times were evaluated. The studied harvests were determined based on the content of soluble solids ( ${ }^{\circ}$ brix). For the first harvest, plants were collected when all varieties had reached ${ }^{\circ}$ brix higher than 18 (which occurred at 407 days, in February 2013 ) and the second collection was defined when the ${ }^{\circ}$ brix of the varieties was close to 20 (which occurred at 483 days, in May 2013), aiming to avoid collection at a highsenescence stage.

Prior to the implementation of the experiment, samples of the soil of the area were collected (0-20 and 20-40 layers) (Table 1) for correction and fertilization, according to the methodology suggested by Embrapa (2009). Next, spontaneous plants and pests such as Diatraea saccharalis (sugarcane borer) were controlled. Subsequently, the soil was plowed, harrowed, and furrowed.

The experimental area was fertilized at the bottoms of the planting furrows, based on the expected productivity (Oliveira et al., 2007; Raij, 2011), utilizing the doses of 100,200 , and $200 \mathrm{~kg}$ of $\mathrm{N}, \mathrm{P}_{2} \mathrm{O}_{5}$, and $\mathrm{K}_{2} \mathrm{O}$, respectively, per hectare.

The sugarcane was planted in 30 plots measuring $5.8 \times 6.0 \mathrm{~m}$ each, with six furrows spaced $1.20 \mathrm{~m}$ apart between furrows. Planting density was 18 to 20 buds per meter of furrow. Stalks were chopped into pieces of two or three buds, deposited into the furrows, and covered with a layer of earth of 5.0 to $8.0 \mathrm{~cm}$.

Plants received complementary irrigation with water from a stream of intermittent flow regime and dendritic drainage pattern. Based on the local precipitation and on the water requirement of the crop, 1,500-2,500 $\mathrm{mm}$ in an annual cycle for productivity of around $150 \mathrm{tha}^{-1}$ (Doorenbos and Kassam, 1994), the water depth was established at $25 \mathrm{~mm} \mathrm{ha}^{-1}$ per week.

The total irrigation depth was $1,041.60 \mathrm{~mm}$, applied between December 2011 and January 2013 (Figure 1), totaling $1,705.90 \mathrm{~mm}$. Total precipitation during the experiment was $664.3 \mathrm{~mm}$ and the average temperature

Table 1 - Results of the chemical analyses of soil from the sugarcane planting areas, in the 0-20 and 20-40 cm depths

\begin{tabular}{|c|c|c|c|c|c|c|c|c|c|c|c|}
\hline Depth & $\mathrm{pH}$ & $\mathrm{P}$ & $\mathrm{K}$ & $\mathrm{Na}$ & $\mathrm{Ca}$ & $\mathrm{Mg}$ & $\mathrm{Al}$ & $\mathrm{H}+\mathrm{Al}$ & SB & $\mathrm{CEC}^{1}$ & BS \\
\hline $\mathrm{cm}$ & & $\mathrm{mg} \mathrm{dm}^{-3}$ & & ------ & ------ & $---\mathrm{cm}$ & 3----- & ------- & --- & & $\%$ \\
\hline $0-20$ & 6.45 & 0.20 & 0.17 & 0.23 & 0.80 & 1.40 & 0.10 & 0.83 & 2.60 & 3.43 & 75.9 \\
\hline
\end{tabular}

SB - sum of bases; CEC - cation-exchange capacity; BS - base saturation.

${ }^{1}$ At pH 7.0. 
was $27.55^{\circ} \mathrm{C}$ (Figure 1) (INMET, 2013), which caused a reduction of the water volume of the stream.

At the moment of harvest, the plants from the two central rows of each plot, excluding one meter from the borders, were cut near the soil level and weighed to determine the fresh matter (FM) yield per hectare. Next, the viable (VS) and unviable stalks were counted, with stalks considered unviable when they were dry. Based on the VS fraction, 10 samples were sub-sampled for the count of total internodes, percentage of uncovered internodes, stalk diameter, stalk length, and top length. Subsequently, five plants from this fraction were used for the middle internode density (MID), according to the methodology adopted by Klein (2010).

For productivity of green leaves, dead leaves, tops, stalks, and whole plant in FM and dry matter (DM), five plants per plot were sub-sampled from the VS fraction. These were weighed and then ground through a forage chopper and dried in an oven at $55^{\circ} \mathrm{C}$ for $72 \mathrm{~h}$, to obtain the DM.

The samples of marketable stalks were ground in a forage chopper and homogenized. A sub-sample of $500 \pm 1.0 \mathrm{~g}$ of stalks was pressed at $250 \mathrm{kgf} \mathrm{cm}^{-2}$ for $60 \mathrm{~s}$ to separate the juice and the bagasse. The juice was analyzed for soluble solids (Brix) and apparent sucrose (Pol). Analyses were conducted according to methods described by Fernandes (2000). Based on the Brix, Pol, juice volume, and marketable-stalk production values, the Brix and Pol yields were calculated, as described by Fernandes (2000).

The samples from the two harvest times were dried in forced-air ovens at $55{ }^{\circ} \mathrm{C}$ for $72 \mathrm{~h}$, ground through $1.0-\mathrm{mm}$ sieves in a Wiley mill, and analyzed according to AOAC (1990) for determinations of DM (ID 930.15), OM (ID 942.05), and crude protein (CP) (ID 954.01). The ether extract (EE) contents were determined using the filter bag developed by Ankom ${ }^{\circledR}$ Technology (2001).

The methods described by Van Soest et al. (1991) were utilized to determine the acid detergent fiber (ADF)

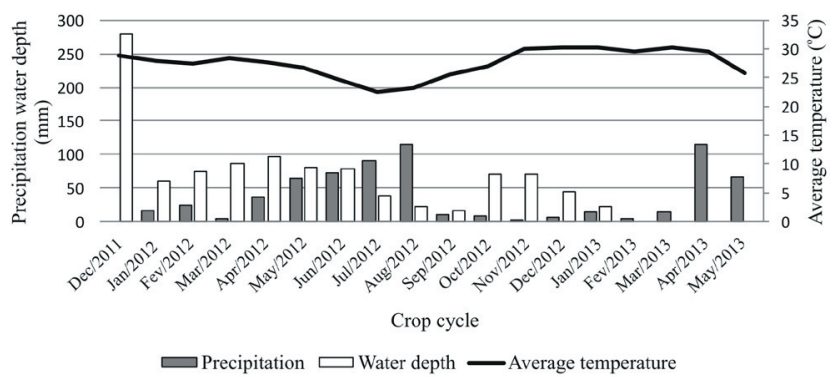

Figure 1 - Precipitation, water depth, and average temperature during the crop cycle in the semi-arid region of Pernambuco State, Brazil ( $8^{\circ} 56^{\prime} 31^{\prime \prime} \mathrm{S}$ latitude and $36^{\circ} 36^{\prime} 24^{\prime \prime}$ W longitude). contents, expressed as free of residual ash, and neutral detergent fiber, also expressed as free of residual ash (NDFom). The neutral detergent insoluble nitrogen (NDIN) and acid detergent insoluble nitrogen (ADIN) contents were determined according to Licitra et al. (1996). For the determinations of neutral detergent insoluble protein (NDIP) and acid detergent insoluble protein (ADIP), the NDIN and ADIN contents were multiplied by 6.25 . The in vitro dry matter digestibility (IVDMD) values were determined according to Tilley and Terry (1963), following modifications described by Holden (1999), using the artificial rumen developed by TECNAL ${ }^{\circledR}$. The in vitro NDF digestibility (IVNDFD) was determined by using recommendations of Tilley and Terry (1963).

Concentrations of total carbohydrates (TC) were estimated by the following equation proposed by Sniffen et al. (1992): $\mathrm{TC}=100-(\mathrm{CP}+\mathrm{EE}+\mathrm{MM})$, in which $\mathrm{MM}=$ mineral matter. Carbohydrate fractions were estimated as follows: fibrous carbohydrates (FC), considered as NDF corrected for ash and protein (NDFap); non-fibrous carbohydrates (NFC), i.e., fractions $\mathrm{A}+\mathrm{B} 1$, obtained by subtracting NDFap from $\mathrm{TC}$; fraction $\mathrm{C}=\mathrm{LIG} \times 2.4$; and fraction $\mathrm{B} 2$, corresponding to the available fraction of the fiber, as the difference between NDFap and fraction C.

Estimates of the truly digestible nutrients and the total digestible nutrients (TDN) were calculated according to National Research Council (NRC, 2001).

The experiment was designed as randomized blocks, in a $5 \times 2$ factorial arrangement (five sugarcane varieties and two evaluation times: 407 and 483 days after planting), with three replicates per treatment.

Data were analyzed by the MIXED procedure of SAS (Statistical Analysis System, version 9.1). The sugarcane variety $(\mathrm{V})$, the harvest time after planting $(\mathrm{T})$, and their interaction $(\mathrm{V} \times \mathrm{T})$ were considered fixed effects. Blocks were considered random effects, according to the following model:

$$
\mathrm{Y}_{\mathrm{ijk}}=\mu+\mathrm{V}_{\mathrm{i}}+\mathrm{T}_{\mathrm{j}}+\mathrm{VT}_{\mathrm{ij}}+\mathrm{b}_{\mathrm{k}}+\varepsilon_{\mathrm{ijk}}
$$

in which $Y_{\mathrm{ijk}}=$ measurable dependent variable; $\mu$ = overall mean; $V_{i}=$ fixed effect of variety; $T_{j}=$ fixed effect of harvest time $\mathrm{j} ; \mathrm{VT}_{\mathrm{ij}}=$ fixed effect of the interaction between variety $\mathrm{i}$ and time $\mathrm{j} ; \mathrm{b}_{\mathrm{k}}=$ random effect of block $\mathrm{k}$; and $\varepsilon_{\mathrm{ijk}}=$ unobservable random effect (NID).

Significance was evaluated by the F test and Tukey test, adopting 0.05 as the critical level of probability for type-I error.

\section{Results}

There was an interaction effect $(\mathrm{P}<0.05)$ between the varieties and harvest times studied on variables such 
as number of uncovered internodes and MID (Table 2), whose interactions were evaluated separately (Table 3). The varieties harvested at 407 days showed a similar percentage of uncovered internodes $(11.39 \%)$ and at 483 days, all variables showed a significant increase in these variables $(\mathrm{P}<0.05)$, with $\mathrm{RB} 98710$ having the highest values, followed by RB 863129 and RB 867515 .

As regards MID, at 407 days, there was no significant difference $(\mathrm{P}>0.05)$ among the varieties $\left(1.19 \mathrm{~g} \mathrm{~cm}^{-3}\right)$. However, at 483 days, a similar response to that was observed, with varieties RB 863129 and RB 98710 showing the highest values, respectively.

The sugarcane varieties evaluated differed $(\mathrm{P}<0.05)$ as to the number of viable stalks, unviable stalks, total internodes, and stalk diameter, and it should be stressed that the harvest time was also significant for total internodes. Stalk length and top length did not differ among the varieties, averaging 155.47 and $35.65 \mathrm{~cm}$, respectively (Table 2).

Variety RB98710 showed the highest number of viable stalks, while RB 867515 had the lowest number. The variable

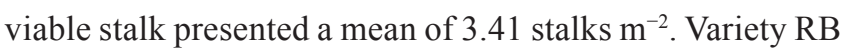
92579 displayed the highest number of unviable stalks and the other varieties did not differ amongst themselves.

The highest number of total internodes was found in RB 943365, differing among the other varieties (except for
RB 92579). Stalk diameter was lowest in RB 98710 and other varieties of sugarcane evaluated did not differ from each other.

There was a significant difference $(\mathrm{P}<0.05)$ among the studied varieties for the DM, OM, MM, and TDN contents (Table 4). Regarding the harvest times, only the DM and IVNDFD contents had a significant difference $(\mathrm{P}<0.05)$, with the DM and IVNDFD contents being lower at 483 days. For the other variables, no differences were detected among the varieties or harvest times (Table 4).

Dry matter content was higher in varieties RB 867515, RB 943365, and RB 92579; between the harvest times, DM yield declined at 483 days (Table 4). Organic matter contents were similar among the varieties, except for RB 867515 , for which it was superior to the others.

The IVNDFD variable was influenced by the time, decreasing by $53.62 \mathrm{~g} \mathrm{~kg}^{-1}$ at 483 days. For the TDN content, variety RB 867515 was superior to RB 98710 and RB 863129.

In the fractionation of carbohydrates (Table 5), there was no interaction effect $(\mathrm{P}>0.05)$ among varieties and harvest times. However, variables $\mathrm{TC}$ and $\mathrm{A}+\mathrm{B} 1$ displayed differences $(\mathrm{P}<0.05)$ among the varieties. Variety RB 867515 showed the highest TC content as compared with RB 863129, RB 92579, and RB 943365. Fractions FC, B2, and C were not different among the varieties or harvest time.

Table 2 - Biometric measurements of sugarcane varieties

\begin{tabular}{|c|c|c|c|c|c|c|c|c|c|c|c|}
\hline \multirow{2}{*}{ Variable } & \multicolumn{5}{|c|}{ Variety (V) } & \multicolumn{2}{|c|}{ Time $(\mathrm{T})^{1}$} & \multirow{2}{*}{ SEM } & \multicolumn{3}{|c|}{ P-value } \\
\hline & RB 863129 & RB 867515 & RB 92579 & RB 943365 & RB 98710 & 407 & 483 & & V & $\mathrm{T}$ & $\mathrm{V} \times \mathrm{T}$ \\
\hline Viable stalks $\left(\mathrm{n} \mathrm{m}^{-2}\right)$ & $3.39 \mathrm{ab}$ & $2.60 \mathrm{~b}$ & $3.60 \mathrm{ab}$ & $3.15 \mathrm{ab}$ & $4.30 \mathrm{a}$ & 3.42 & 3.39 & 1.32 & 0.0469 & 0.9498 & 0.9981 \\
\hline Unviable stalks $\left(\mathrm{n} \mathrm{m}^{-2}\right)$ & $0.30 \mathrm{~b}$ & $0.24 b$ & $0.76 \mathrm{a}$ & $0.35 \mathrm{ab}$ & $0.23 b$ & 0.32 & 0.43 & 0.35 & 0.0088 & 0.2914 & 0.5038 \\
\hline Total internodes & $13.55 \mathrm{~b}$ & $16.58 \mathrm{ab}$ & $12.99 \mathrm{~b}$ & $19.49 \mathrm{a}$ & $14.59 \mathrm{~b}$ & 12.98 & 17.90 & 1.46 & 0.0007 & $<0.0001$ & 0.9842 \\
\hline Uncovered internodes (\%) & 31.44 & 34.63 & 20.15 & 27.17 & 43.78 & 11.39 & 51.48 & 4.40 & 0.0005 & $<0.0001$ & 0.0049 \\
\hline Stalk diameter $(\mathrm{mm})$ & $29.55 \mathrm{a}$ & $30.65 \mathrm{a}$ & $27.85 \mathrm{a}$ & $28.49 \mathrm{a}$ & $23.28 b$ & 28.10 & 27.83 & 1.14 & $<0.0001$ & 0.7211 & 0.3639 \\
\hline Stalk length $(\mathrm{cm})$ & 156.25 & 177.18 & 138.10 & 155.94 & 149.57 & 158.69 & 152.12 & 18.58 & 0.2749 & 0.5490 & 0.5261 \\
\hline Top length $(\mathrm{cm})$ & 38.70 & 36.61 & 35.79 & 34.57 & 32.56 & 34.51 & 36.78 & 3.05 & 0.3725 & 0.2541 & 0.6369 \\
\hline $\operatorname{MID}\left(\mathrm{g} \mathrm{cm}^{-3}\right)$ & 1.50 & 1.36 & 1.40 & 1.40 & 1.48 & 1.19 & 1.67 & 0.07 & 0.2832 & $<0.0001$ & 0.0142 \\
\hline
\end{tabular}

MID - middle internode density; SEM - standard error of the mean.

${ }^{1}$ Days after planting.

Means followed by common lowercase letters in the row do not differ by Tukey's test at 0.05 probability level.

Table 3 - Interaction between variety and days after planting (DAP) on biometric measurements of sugarcane varieties

\begin{tabular}{|c|c|c|c|c|c|c|}
\hline & \multicolumn{5}{|c|}{ Variety (V) } & \multirow{2}{*}{ P-value } \\
\hline & RB 863129 & RB 867515 & RB 92579 & RB 943365 & RB 98710 & \\
\hline \multicolumn{7}{|c|}{ Uncovered internodes (\%) } \\
\hline 483 DAP & $52.64 \mathrm{~b}$ & $58.07 \mathrm{~b}$ & $35.82 \mathrm{c}$ & $38.09 \mathrm{c}$ & $72.76 \mathrm{a}$ & $<0.001$ \\
\hline P-value & $<0.001$ & $<0.001$ & 0.001 & 0.0019 & $<0.001$ & \\
\hline \multicolumn{7}{|c|}{ Middle internode density $\left(\mathrm{g} \mathrm{cm}^{-3}\right)$} \\
\hline P-value & $<0.0001$ & 0.0001 & 0.0159 & 0.0052 & $<0.0001$ & \\
\hline
\end{tabular}

Means followed by common lowercase letters in the row do not differ by Tukey's test at 0.05 probability level. 
For total productivity and the productivity of the sugarcane parts fractionated into fresh and dry matter, there was no interaction effect between the analyzed variables and harvest times, except $(\mathrm{P}<0.05)$ for the amount of total fresh matter and fresh matter of stalks produced (Table 6). However, there was an effect $(\mathrm{P}<0.05)$ of harvest time on the amount of FM and DM of tops produced and green leaf DM, which were lower at 483 days.

There were no significant differences $(\mathrm{P}>0.05)$ for FM production at 407 days among the sugarcane varieties evaluated, averaging $100.64 \mathrm{t} \mathrm{ha}^{-1}$. However, at 483 days, the highest $(\mathrm{P}<0.05)$ FM production was found in $\mathrm{RB}$ 863129, followed by RB 943365 (Table 7). The variety RB 863129 presented higher yield $(\mathrm{P}<0.05)$ of $\mathrm{FM}$ production at 483 days and RB 867515 at 407 days. The other varieties were similar between harvest times. The varieties produced the same amount of stalk FM at 407 days, whose average was $81.36 \mathrm{t} \mathrm{ha}^{-1}$ (Table 7). At 483 days, varieties RB 863129 and RB 98710 showed the highest and lowest production, respectively. Concerning the harvest times, the amount of

Table 4 - Chemical composition of five sugarcane varieties

\begin{tabular}{|c|c|c|c|c|c|c|c|c|c|c|c|}
\hline \multirow{2}{*}{ Variable } & \multicolumn{5}{|c|}{ Variety (V) } & \multicolumn{2}{|c|}{ Time $(\mathrm{T})^{1}$} & \multirow{2}{*}{ SEM } & \multicolumn{3}{|c|}{ P-value } \\
\hline & RB 863129 & RB 867515 & RB 92579 & RB 943365 & RB 98710 & 407 & 483 & & V & $\mathrm{T}$ & $\mathrm{V} \times \mathrm{T}$ \\
\hline $\mathrm{DM}\left(\mathrm{g} \mathrm{kg}^{-1}\right)$ & $266.33 b$ & $289.28 \mathrm{a}$ & $282.37 \mathrm{a}$ & $300.39 a$ & $274.14 b$ & 294.21 & 270.80 & 11.21 & 0.0489 & 0.0032 & 0.0558 \\
\hline $\mathrm{OM}\left(\mathrm{g} \mathrm{kg}^{-1}\right)$ & $955.45 b$ & $967.27 \mathrm{a}$ & $952.38 b$ & $959.63 b$ & $959.65 b$ & 957.62 & 960.13 & 3.82 & 0.0080 & 0.2856 & 0.2322 \\
\hline $\mathrm{MM}\left(\mathrm{g} \mathrm{kg}^{-1}\right)$ & $47.22 \mathrm{a}$ & $34.96 \mathrm{~b}$ & $46.38 \mathrm{a}$ & $42.54 \mathrm{a}$ & $42.88 \mathrm{a}$ & 43.52 & 42.08 & 3.94 & 0.0179 & 0.5174 & 0.0829 \\
\hline Lignin $\left(\mathrm{g} \mathrm{kg}^{-1}\right)$ & 41.97 & 40.88 & 37.13 & 39.09 & 42.66 & 39.65 & 41.04 & 2.24 & 0.1269 & 0.3328 & 0.0910 \\
\hline $\mathrm{NDF}\left(\mathrm{g} \mathrm{kg}^{-1}\right)$ & 508.47 & 444.40 & 477.18 & 473.43 & 484.20 & 481.59 & 473.48 & 21.69 & 0.0861 & 0.5473 & 0.1168 \\
\hline $\operatorname{ADF}\left(\mathrm{g} \mathrm{kg}^{-1}\right)$ & 264.22 & 266.88 & 261.00 & 257.04 & 267.85 & 263.95 & 262.84 & 10.16 & 0.7946 & 0.8585 & 0.2424 \\
\hline IVDMD (\%) & 618.82 & 608.98 & 626.76 & 632.73 & 618.17 & 630.95 & 611.23 & 16.06 & 0.6431 & 0.0665 & 0.4229 \\
\hline IVNDFD (\%) & 476.95 & 458.70 & 512.60 & 493.24 & 484.97 & 512.10 & 458.48 & 26.57 & 0.3175 & 0.0032 & 0.4624 \\
\hline TDNm $\left(\mathrm{Mcal} \mathrm{kg}^{-1}\right)$ & $648.18 \mathrm{c}$ & $676.60 \mathrm{a}$ & $666.35 \mathrm{ab}$ & $666.71 \mathrm{ab}$ & $656.14 b c$ & 661.23 & 664.37 & 9.87 & 0.0300 & 0.5592 & 0.2857 \\
\hline
\end{tabular}

DM - dry matter; OM - organic matter; MM - mineral matter; NDF - neutral detergent fiber; ADF - acid detergent fiber; IVDMD - in vitro DM digestibility; IVNDFD - in vitro NDF digestibility; TDNm - total digestible nutrients for animals on maintenance requirements; SEM - standard error of the mean.

${ }^{1}$ Days after planting.

Means followed by common lowercase letters do not differ in the rows among the varieties by the $\mathrm{F}$ test at 0.05 probability level.

Table 5 - Fractionation of carbohydrates of five sugarcane varieties

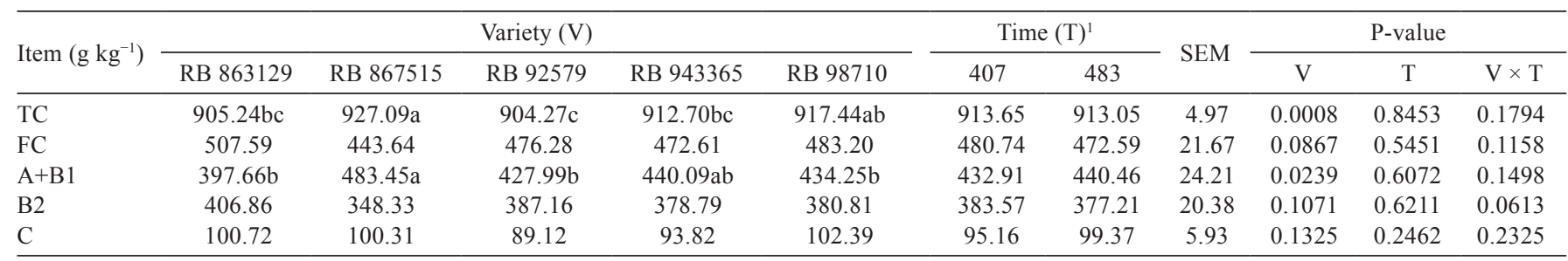

TC - total carbohydrates; FC - fibrous carbohydrates; A+B1 - non-structural carbohydrates; B2 - available fiber fraction; C - indigestible fraction; SEM - standard error of the mean.

${ }^{1}$ Days after planting.

Means followed by common lowercase letters do not differ in the rows among the varieties by the $\mathrm{F}$ test at 0.05 probability level.

Table 6 - Total sugarcane yield and yield of sugarcane fractionated into green leaves, dry leaves, tops, and stalks in the fresh and dry matter

\begin{tabular}{|c|c|c|c|c|c|c|c|c|c|c|c|}
\hline \multirow{2}{*}{ Item $\left(\mathrm{t} \mathrm{ha}^{-1}\right)$} & \multicolumn{5}{|c|}{ Variety (V) } & \multicolumn{2}{|c|}{ Time $(\mathrm{T})^{1}$} & \multirow{2}{*}{ SEM } & \multicolumn{3}{|c|}{ P-value } \\
\hline & RB 863129 & RB 867515 & RB 92579 & RB 943365 & RB 98710 & 407 & 483 & & $\mathrm{~V}$ & $\mathrm{~T}$ & $\mathrm{~V} \times \mathrm{T}$ \\
\hline Total FM & 117.54 & 104.13 & 90.98 & 98.59 & 88.68 & 100.64 & 99.33 & 9.38 & 0.0227 & 0.8106 & 0.0044 \\
\hline DL-FM & 5.52 & 4.03 & 4.97 & 4.52 & 3.62 & 4.48 & 4.58 & 1.06 & 0.4291 & 0.8840 & 0.3525 \\
\hline Top-FM & 7.67 & 5.61 & 6.36 & 6.29 & 5.50 & 7.42 & 5.15 & 1.07 & 0.2398 & 0.0020 & 0.4139 \\
\hline S-FM & 96.15 & 88.94 & 72.65 & 81.21 & 66.20 & 81.36 & 80.70 & 9.12 & 0.0255 & 0.9107 & 0.0078 \\
\hline Total DM & 33.97 & 34.86 & 26.89 & 30.34 & 25.50 & 32.53 & 28.09 & 3.96 & 0.0827 & 0.0774 & 0.1545 \\
\hline Top-DM & 1.96 & 1.97 & 1.85 & 1.94 & 1.46 & 2.54 & 1.14 & 0.31 & 0.4220 & $<0.0001$ & 0.1329 \\
\hline S-DM & 24.33 & 26.97 & 19.03 & 22.83 & 18.72 & 23.32 & 21.43 & 3.28 & 0.0828 & 0.3600 & 0.1266 \\
\hline
\end{tabular}

Total FM - total fresh matter; DL-FM - dry leaves in the fresh matter; GL-FM - green leaves in the fresh matter; Top-FM - tops in the fresh matter; S-FM - stalks in the fresh matter; Total DM - total dry matter; DL-DM - dry leaves in the dry matter; GL-DM - green leaves in the dry matter; Top-DM - tops in the dry matter; S-DM - stalks in the dry matter; SEM - standard error of the mean.

${ }^{1}$ Days after planting. 
stalk FM produced was greater at 483 days for RB 863129 and at 407 days for RB 867515 ; the other variables showed the same production at both times (Table 7).

In the analysis of Brix and Pol yields per hectare, it was observed that the variables ton of Brix per hectare (TBH) and ton of sucrose per hectare (TSH) averaged 15.12 and $10.14 \mathrm{t} \mathrm{ha}^{-1}$, respectively, and the NDF:Brix and NDF:Pol ratios were higher for variety RB 863129 (Table 8).

\section{Discussion}

Some biometric variables may influence the nutritional quality of the sugarcane and be indicative of the productive capacity of the canebrake in response to soil-climatic factors, such as viable stalk, stalk diameter, and number of internodes. The MID values found in this study were notably higher than the $1.05-1.58 \mathrm{~g} \mathrm{~cm}^{-3}$ reported in the literature (Azzini et al., 1986; Klein, 2010), indicating that the varieties showed higher accumulations of sucrose, especially varieties RB 863129 and RB 98710 at 483 days. This variable, according to Azzini et al. (1986) and Fernandes (2000), is positively correlated with Brix and Pol, which indirectly determine the concentration of sucrose (Oliveira et al., 2012). Therefore, stalk density is a variable that can predict the concentration of sucrose in the plant in a simple and economic manner.

The variable total internodes has a negative correlation with the ease of cutting and with the digestibility. Therefore, as the values of total internodes are increased, the forage digestibility is reduced, due to the higher number of nods (Klein, 2010). In the present study, varieties RB 867515 and RB 943365 showed the highest values of total internodes. This variable also allows the identification of varieties that least adapt to the environment, since an increase in total internodes may be associated with water deficiency, because internode elongation is reduced, culminating in short internodes near each other (Câmara, 1993; Benett et al., 2011). Thus, the average length observed in this study $(191.12 \mathrm{~cm})$ was lower than the $200.5 \mathrm{~cm}$ found in the literature. This can be explained by the climatic effects that took place during the study, especially at 483 days, when the water depth was lower (Figure 1) and provided a higher total internodes, reducing plant size, because the average water depth became $14.25 \mathrm{~mm} \mathrm{ha}^{-1}$ per week, which was insufficient to meet the crop requirements.

The values of viable stalks observed in the present study (2.60-4.30 stalks $\left.\mathrm{m}^{-2}\right)$ were below the $5-5.42$ stalks $\mathrm{m}^{-2}$ recommended in the literature for good establishment and perenniality aiming at animal feeding (Landell et al., 2002). Addressing the unviable stalks, Klein (2010) associated lower values of this variable to greater productivity. Variety RB 92579 showed the largest number of unviable stalks, showing to be one of the least productive in this study (Table 2).

Based only on the biometric characteristics, varieties RB 92579 and RB 943365 showed the worst performance as evaluated by agronomic characteristics (high unviable

Table 7 - Interaction between varieties and days after planting (DAP) on total productivity and fractionated productivity (green leaves, dry leaves, tops, and stalks in the fresh and dry matter) of sugarcane

\begin{tabular}{|c|c|c|c|c|c|c|}
\hline \multirow{2}{*}{ Time } & \multicolumn{5}{|c|}{ Variety } & \multirow{2}{*}{ SEM } \\
\hline & RB 863129 & RB 867515 & RB 92579 & RB 943365 & RB 98710 & \\
\hline \multicolumn{7}{|c|}{ Fresh matter $\left(\mathrm{t} \mathrm{ha}^{-1}\right)$} \\
\hline 407 DAP & $99.79 B$ & $123.96 \mathrm{~A}$ & 98.05 & 91.94 & 89.44 & 0.0710 \\
\hline 483 DAP & $135.28 \mathrm{aA}$ & $84.30 \mathrm{cB}$ & $83.90 \mathrm{c}$ & $105.25 b$ & $87.91 \mathrm{c}$ & 0.0018 \\
\hline P-value & 0.0086 & 0.0040 & 0.2548 & 0.2832 & 0.9002 & \\
\hline \multicolumn{7}{|c|}{ Stalk fresh matter $\left(\mathrm{t} \mathrm{ha}^{-1}\right)$} \\
\hline 407 DAP & $76.82 \mathrm{~B}$ & $104.97 \mathrm{~A}$ & 77.64 & 73.27 & 74.10 & 0.1143 \\
\hline 483 DAP & $115.49 \mathrm{aA}$ & $72.92 \mathrm{bcB}$ & $67.66 \mathrm{bc}$ & $89.16 b$ & $58.30 \mathrm{c}$ & 0.0023 \\
\hline P-value & 0.0071 & 0.0219 & 0.4479 & 0.2323 & 0.2347 & \\
\hline
\end{tabular}

Means followed by common lowercase letters in the rows and uppercase letters in the columns do not differ by Tukey's test at 0.05 probability level.

Table 8 - Soluble solids and sucrose yields and ratios between neutral detergent fiber (NDF) and these variables

\begin{tabular}{|c|c|c|c|c|c|c|c|c|c|c|c|}
\hline \multirow{2}{*}{ Item } & \multicolumn{5}{|c|}{ Variety (V) } & \multicolumn{2}{|c|}{ Time $(\mathrm{T})^{1}$} & \multirow{2}{*}{ SEM } & \multicolumn{3}{|c|}{ P-value } \\
\hline & RB 863129 & RB 867515 & RB 92579 & RB 943365 & RB 98710 & 407 & 483 & & V & $\mathrm{T}$ & $\mathrm{V} \times \mathrm{T}$ \\
\hline TBH $\left(\mathrm{t} \mathrm{ha}^{-1}\right)$ & 16.62 & 16.92 & 13.76 & 15.99 & 12.32 & 15.40 & 14.85 & 2.01 & 0.1279 & 0.6664 & 0.0507 \\
\hline $\mathrm{TSH}\left(\mathrm{t} \mathrm{ha}^{-1}\right)$ & 10.91 & 11.40 & 9.24 & 11.04 & 8.14 & 10.57 & 9.72 & 1.45 & 0.1318 & 0.3489 & 0.0677 \\
\hline NDF:Brix & $2.93 \mathrm{a}$ & $2.34 \mathrm{c}$ & $2.50 \mathrm{~b}$ & $2.42 b$ & $2.60 \mathrm{~b}$ & 2.57 & 2.55 & 0.14 & 0.0013 & 0.7987 & 0.1986 \\
\hline NDF:Pol & $3.68 \mathrm{a}$ & $2.84 \mathrm{c}$ & $3.09 b c$ & $2.88 b c$ & $3.22 \mathrm{~b}$ & 3.10 & 3.19 & 0.22 & 0.0010 & 0.4126 & 0.2501 \\
\hline
\end{tabular}

TBH - ton of Brix per hectare; TSH - ton of sucrose per hectare; SEM - standard error of the mean.

${ }^{1}$ Days after planting.

Means followed by common lowercase letters do not differ in the rows among the varieties by the F test at 0.05 probability level. 
stalks and total internodes and low uncovered internodes), although productive responses are more positive in other studies. According to RIDESA (2010), variety RB 92579 has a slow growth, while RB 946635 has a regular growth speed. Thus, the aggravation of the drought during this study, which reduced the water depth, caused these varieties to have the worst performance.

The influence of the chemical and digestibility characteristics on plant growth can be demonstrated by the decrease in DM and IVNDFD contents at 483 days. Overall, the increase in the sugarcane DM contents is related to an increase in the concentration of soluble carbohydrates, mainly sucrose (Fernandes, 2000; Oliveira et al., 2012). Thus, the reduction of sucrose and the elevation of reducing sugars contribute to decreasing DM.

Average NDF contents were lower than the average $540 \mathrm{~g} \mathrm{~kg}^{-1}$ reported in the literature (Cruz et al., 2010; Freitas et al., 2006; Mello et al., 2006) and the average ADF contents of the present study were lower than the 284-335 $\mathrm{g} \mathrm{kg}^{-1}$ described by Cruz et al. (2010). In general, the NDF values in sugarcane are not high; however, the fiber quality is low and as the NDF content is increased, digestibility decreases (Van Soest, 1994). The higher IVDMD values are related to the lower lignifications of the cell wall, since this variable is negatively correlated with lignin, NDF, and ADF. Thus, the studied varieties presented similarities for these variables and, consequently, showed similar IVDMD values (Table 4). Therefore, the varieties studied here showed superior nutritional quality to some reports found in the literature (Freitas et al., 2006; Mello et al., 2006; Cruz et al., 2010).

The higher TDN values observed in variety $\mathrm{RB}$ 867515 are due to its greater NFC content (Table 5), since, according to Van Soest (1994), the NFC content influences the TDN values, because these carbohydrates are almost entirely available to the microbiota of ruminants. Fractions A+B1 were higher in varieties RB 867515 and RB 943365 , characterizing them as varieties that have carbohydrates of high rumen degradation and, thus, they can positively influence the animal performance.

Compared with older genetically improved varieties in Brazil, the varieties utilized in this study show, in general, good chemical properties, even under low water availability conditions. It can be noted that the lignin contents found in the current study are below the values cited in the literature (Freitas et al., 2006; Mello et al., 2006; Cruz et al., 2010). Therefore, it can be inferred that the fiber digestibility values can be higher. As a consequence, problems such as rumen fill and reduced intake may be smaller with these varieties. According to Carvalho et al. (2010), the digestibility of fiber is a greater limiting factor to animal performance than the dry matter digestibility is, because the digestibility of fiber is more closely related to quality than quantity.

In investigating the quality of the chemical composition of each variety, the best variety was RB867515 (high levels of DM, OM, TDN, TC, and A+B1), followed by RB 943365 (high DM, MM, TDN, and A+B1), and, lastly, RB 92579 (high DM, MM, and TDN contents).

The effect of harvest time was less pronounced on the amount of FM and DM of tops produced and on green leaf DM at 483 days, which is probably associated with the soil water deficit resulting from the reduced irrigation depth between the 407th and 483rd days $(21.96 \%)$. Thus, the decreased production of RB 867515 from 407 to 483 days may be related to the characteristics of dehydration of stalk tissues and the environmental requirements, classified, according to RIDESA (2010), as medium stalk dehydration and medium environmental restriction, respectively. Regarding total FM and DM production, the varieties behaved similarly (Table 6), as they also did in both harvest times. This similarity is a result of the observed leaf area index (unpublished data), since the varieties showed the same photosynthetic rate per surface unit.

The lowest productivity was obtained with RB 98710 (88.68 $\mathrm{t} \mathrm{ha}^{-1}$ ) (Table 6) stemming from the lower stalk productivity. However, for stalk viability, this variety was ranked third (77.7\%), only after RB 867515 (91.19\%) and RB $863129(81.79 \%)$. The TBH and TSH yields were similar because of the productivity, especially of stalks, which was similar (Table 6).

A decrease was observed in the NDF:Brix and NDF:Pol rations, in varieties $\mathrm{RB} 867515$, RB 92579, and RB 943365. The reduction of the NDF:Pol ratio contributed to increasing digestibility values, leading to greater energy intake (Siqueira et al., 2012). According to Mello et al. (2006), this parameter is important in the choice of varieties for ruminant feeding, as its average is lower than $3.03 \%$. Addressing the NDF:Brix ratio, Rodrigues et al. (1997) recommended a value below $2.7 \%$ as adequate for ruminants to prevent the higher NDF content from limiting the intake of digestible energy. Thus, these three varieties stood out.

\section{Conclusions}

Sugarcane variety RB 867515 is suggested for forage production in semi-arid conditions, since it is best adapted to the local soil-climatic conditions and to the water deficit, especially at 407 days after planting. Although varieties RB 92579 and RB 943365 present good chemical 
characteristics and ratios between NDF and Brix and Pol, they are more vulnerable to the water stress and, consequently, more unstable to establish sugarcane fields for forage purposes under the same conditions as those of the present study.

\section{Acknowledgments}

The authors thank $\mathrm{CNPq}$ for the financial support provided through Edital Universal (484611/2011-9); Capes, for the Post-Graduate fellowship grant (Masters in Animal Science and Pastures from Universidade Federal Rural de Pernambuco/Unidade Acadêmica de Garanhuns); the sugarcane breeders Djalma Euzébio and Gerson Quirino, for indicating and donating the sugarcane varieties for the present study; Triunfo Mill (Rio Largo-AL); the researcher Manoel Gomes Pereira, for providing the space for the analyses of marketable stalks; and Professor Stefanie Alvarenga, from Universidade Federal da Bahia, for the statistical guidance.

\section{References}

Ankom. 2001. Method for crude fat determinations. Available at: $<$ http://www.ankom.com>. Accessed on: Jun. 12, 2013.

AOAC - Association of Official Analytical Chemistry. 1990. Official methods of analysis. 15th ed. AOAC International, Arlington, VA.

Azzini, A.; Zullo, M. A. T.; Arruda, M. C. Q.; Bastos, C. R. and Costa, A. A. 1986. Densidade básica do colmo e sua correlação com os valores de brix e pol em cana-de-açúcar. Bragantia 45:155-160.

Benett, C. G. S.; Buzetti, S.; Silva, K. S.; Teixeira Filho, M. C. M.; Garcia, C. M P. and Maestrelo, P. R. 2011. Produtividade e desenvolvimento da cana-planta e soca em função de doses e fontes de manganês. Revista Brasileira de Ciência do Solo 35:1661-1668.

Borges, A. L. C. C.; Silva, R. R.; Lage, H. F.; Borlini, D. C. and Campos, M. M. 2012. The use of sugarcane as a feed source for dairy cattle. Veterinary \& Animal Science Magazine 1:36-46.

Câmara, G. M. S. 1993. Ecofisiologia da cana-de-açúcar. p.31-64. In: Produção de cana-de-açúcar. Câmara, G. M. S. and Oliveira, E. A. M., eds. FEALQ, Piracicaba.

Carvalho, M. V.; Rodrigues, P. H. M.; Lima, M. L. P.; Anjos, I. A.; Landell, M. G. A.; Santos, M. V. and Prada e Silva, L. F. 2010. Composição bromatológica e digestibilidade de cana-de-açúcar colhida em duas épocas do ano. Brazilian Journal of Veterinary Research and Animal Science 47:298-306.

Cruz, P. G.; Figueiredo, M. P.; Pereira, L. G. R.; Bergamaschi, K. B.; Rodrigues, C. S. and Rech, C. L. 2010. Fractionation and kinetics of in vitro ruminal fermentation of the carbohydrates of five sugarcane varieties. Ciência Animal Brasileira 11:784-793.

Doorenbos, J. and Kassan, A. H. 1994. Efeito da água no rendimento das culturas. UFPB, Campina Grande, PB.

Embrapa - Empresa Brasileira de Pesquisa Agropecuária. 2006. Sistema brasileiro de classificação de solos. 3.ed. Embrapa Solos, Rio de Janeiro, RJ.

Embrapa - Empresa Brasileira de Pesquisa Agropecuária. 2009. Manual de análises químicas de solos, plantas e fertilizantes. 2.ed. Embrapa Informação Tecnológica, Brasília, DF.
Embrapa - Empresa Brasileira de Pesquisa Agropecuária. 2011. Canade-açúcar. Available at: <http://www.agencia.cnptia.embrapa.br>. Accessed on: Jul. 20, 2013.

Fernandes, A. C. 2000. Cálculos no agronegócio da cana-de-açúcar. STAB - Açúcar, Álcool e Subprodutos, Piracicaba, SP.

Freitas, A. W. P.; Pereira, J. C.; Rocha, F. C.; Detmann, E.; Barbosa, M. H. P.; Ribeiro, M. D. and Costa, M. G. 2006. Avaliação da divergência nutricional de genótipos de cana-de-açúcar (Saccharum spp.). Revista Brasileira de Zootecnia 35:229-236.

Holden, L. A. 1999. Comparison of methods of in vitro dry matter digestibility for ten feeds. Journal of Dairy Science 82:1791-1794.

IBGE - Instituto Brasileiro de Geografia e Estatística. 2013. Sistema IBGE de recuperação automática. Available at: $<$ http://www.sidra. ibge.gov.br/>. Accessed on: Apr. 21, 2013.

INMET - Instituto Nacional de Meteorologia. 2013. Banco de dados meteorológicos para educação e pesquisa: Estação de tempo de Garanhuns-PE. Available at: <http://www.inmet.gov.br/portal/ index.php?r=bdmep/bdmep>. Accessed on: Apr. 21, 2013.

Klein, V. 2010. Características agronômicas, químicas e bromatológicas de variedades de cana-de-açúcar para uso forrageiro. Dissertação (M.Sc.). Universidade Federal de Goiás, Jataí.

Landell, M. G. A.; Campana, M. P.; Rodrigues, A. A.; Cruz, G. M.; Batista, L. A. R.; Figueiredo, P.; Silva, M. A.; Bidoia, M. A. P.; Rossetto, R.; Martins, A. L. M.; Gallo, P. B.; Kanthack, R. A. D.; Cavichioli, J. C.; Vasconcelos, A. C. M. and Xavier, M. A. 2002. A variedade IAC86-2480 como uma nova opção de cana-de-açúcar para fins forrageiros: manejo de produção e uso na alimentação animal. Boletim Técnico IAC 193. Instituto Agronômico, Campinas. 36p.

Landell, M. G. A. 2005. Novas variedades IACSP serão lançadas em outubro de 2005. STAB - Açúcar, Álcool e Subprodutos 24:28-30.

Licitra, G.; Hernandez, T. M. and Van Soest, P. J. 1996. Standardization of procedures for nitrogen fractionation of ruminant feeds. Animal Feed Science and Technology 57:347-358.

Mello, S. Q. S.; França, A. F. S.; Lima, M. L. M.; Ribeiro, D. S.; Miyagi, E. S. and Reis, J. G. 2006. Parâmetros do valor nutritivo de nove variedades de cana-de-açúcar cultivadas sob irrigação. Ciência Animal Brasileira 7:373-380.

NRC - National Research Council. 2001. Nutrient requirements of dairy cattle. 7th rev. ed. National Academic Science, Washington, DC

Oliveira, M. W.; Freire, F. M.; Macedo, G. A. R. and Fereira, J. J. 2007. Nutrição mineral e adubação da cana-de-açúcar. Informe Agropecuário 28:30-43.

Oliveira, M. W.; Silva, V. S. G.; Oliveira, D. C.; Silva, J. C. T. and Reis, R. M. S. 2012. Produção e qualidade da forragem de duas variedades de cana-de-açúcar influenciadas pela adubação com cobre e manganês. Revista Científica de Produção Animal 14:165-168.

Raij, B. 2011. Fertilidade do solo e manjeo de nutrients. 2nd ed. International Plant Nutrition Institute, Piracicaba, SP.

RIDESA - Rede Interuniversitária para o Desenvolvimento do Setor Sucroalcooleiro. 2010. Catálogo nacional de variedades RB de cana-de-açúcar. Curitiba, PR.

RIDESA - Rede Interuniversitária para Desenvolvimento do Setor Sucroalcooleiro. 2012. Censo Varietal Brasil 2012. Available at: $<$ http://ridesa.agro.ufg.br/pages/44741>. Accessed on: Aug. 25, 2013.

Rodrigues, J. D. 1995. Fisiologia da cana-de-açúcar. Available at: $<$ http://pt.scribd.com/doc/6301126/Cana-de-açúcar-Ecofisiologia>. Accessed on: Oct. 4, 2011.

Rodrigues, A. A.; Primavesi, O. and Esteves, S. N. 1997. Efeito da qualidade de variedades de cana-de-açúcar sobre seu valor como alimento para bovinos. Pesquisa Agropecuária Brasileira 32:1333-1338. 
Siqueira, G. R.; Roth, M. T. P.; Moretti, M. H.; Benatti, J. M. B. and Resende, F. D. 2012. Uso da cana-de-açúcar na alimentação de ruminantes. Revista Brasileira de Saúde e Produção Animal 13:991-1008.

Sniffen, C. J.; O’Connor, J. D.; Van Soest, P. J.; Fox, D. G. and Russell, J. B. 1992. A net carbohydrate and protein system for evaluating cattle diets: II. Carbohydrate and protein availability. Journal of Animal Science 70:3562-3577.

Tilley, J. M. A. and Terry, R. A. 1963. A two-state technique for in vitro digestion of forage crops. Journal of the Britsh Grassland Society 18:104-111.

Toppa, E. V. B.; Jadoski, C. J.; Julianetti, A.; Hulshof, T.; Ono, E. O. and Rodrigues, J. D. 2010. Aspectos da fisiologia de produção da cana-de-açúcar (Saccharum officinarum L.). Pesquisa Aplicada \& Agrotecnologia 3:215-221.

Townsend, C. R.; Costa, N. L.; Torres, R. A.; Soares, J. P. G.; Pereira, R. G. A. and Magalhães, J. A. 2006. Avaliação agronômica de variedades de cana-de-açúcar para fins forrageiros em Rondônia. Revista Científica de Produção Animal 8:15-20.

Van Soest, P. J.; Robertson, J. B. and Lewis, B.A. 1991. Methods for dietary fiber, neutral detergent fiber, and no starch polysaccharides in relation to animal nutrition. Journal of Dairy Science 74:35833597.

Van Soest, P. J. 1994. Nutritional ecology of the ruminant. 2nd ed. Comstock Publishing Associated, a division of Cornell University Press, Ithaca, NY. 